\title{
$10 \mathrm{q} 23.2$
}

National Cancer Institute

\section{Source}

National Cancer Institute. 10923.2. NCI Thesaurus. Code C82142.

A chromosome band present on 10q. 